\title{
BICYTOPENIA ASSOCIATED WITH PAROXETINE: A CASE REPORT
}

\author{
Erkan Kuru $^{1}$, İlker Özdemir ${ }^{2}$ \& Mehmet Hakan Türkçapar ${ }^{3}$ \\ ${ }^{I}$ Department of Psychiatry, Boylam Psychiatric Hospital, Ankara, Turkey \\ ${ }^{2}$ Department of Psychiatry, Medical Faculty of Giresun University, Giresun, Turkey \\ ${ }^{3}$ Department of Psychology, Hasan Kalyoncu University, Gaziantep, Turkey
}

received: 19.10.2017;

revised: 5.2.2018;

accepted: 5.3.2018

\section{INTRODUCTION}

Paroxetine is a selective serotonin reuptake inhibitor (SSRI), which is used to treat depression, obsessivecompulsive disorder, panic disorder, social anxiety disorder, generalized anxiety disorder, and post-traumatic stress disorder. In addition to general SSRI adverse effects (nausea, vomiting, indigestion, abdominal pain, diarrhea, rash, sweating, agitation, anxiety, headache, insomnia, chills, sexual dysfunction, hyponatremia), antimuscarinic effects, sedation, extrapyramidal symptoms, and discontinuation symptoms may be more common with paroxetine (Taylor et al. 2015). The most common adverse effects during the use of paroxetine were reported as nausea, drowsiness, stretching, dry mouth, loss of appetite, nervousness, sweating, constipation, and ejaculation disorder (Nevel et al. 2016).

Serotonin provides platelet aggregation and plays a role in the coagulation mechanism (Koçer et al. 2012). The use of SSRIs reduces serotonin stored in platelets, decreases platelet aggregation, and increases risk of bleeding (Oyesanmi et al. 1999, Halperin \& Reber 2007, Sözeri-Varma et al. 2012). The most common hematologic adverse effects are prolonged bleeding time, and reduced platelet aggregation and activity (Halperin \& Reber 2007, Koçbiyık et al. 2015). In addition, SSRIs can cause functional impairment of platelet aggregation, but not reduction in platelet number (Sadock \& Sadock 2011). Although leukopenia and thrombocytopenia are reported to be associated with a large number of antidepressants or antipsychotics (Taylor et al. 2015) only a few cases with paroxetine have been reported in the literature (Koçer et al. 2012, Sözeri-Varma et al. 2012, Moselhy \& Conlon 1999, Trewet et al. 2007, Ono et al. 2013). It is recommended that bleeding parameters should be monitored in patients with bleeding disorder who use SSRIs (Halperin \& Reber 2007, Koçbıyık et al. 2015). During severe leukopenia and neutropenia, morbidity and risk of mortality increases owing to the risk of infection and the complications of infection (Matsuura et al. 2016).

In this case report, we aimed to share with the literature a case of bicytopenia (thrombocytopenia and leukopenia) found incidentally in a patient with major depressive disorder.

\section{CASE REPORT}

The patient was a married woman aged 34 years who was a university graduate, and civil servant. The patient visited our outpatient clinic with symptoms of insomnia, unhappiness, not enjoying life, loss of appetite, and weakness, which had continued for two months. It was her first presentation to the psychiatry outpatient clinic. She had no additional medical illnesses, had no psychiatric history or family history. In her first psychiatric examination, she had decreased spontaneous attention, depressed mood, and felt sad. She had depressive ruminations in her thought content and slowing in her psychomotor movements. She was diagnosed as having major depressive disorder in accordance with the fifth edition of the Diagnostic and Statistical Manual of Mental Disorders (DSM-5) and pharmacotherapy started with paroxetine $20 \mathrm{mg} /$ day. She was evaluated using the Beck Depression Inventory (BDI). Her first BDI score was 31. About three weeks after treatment onset, she was admitted to the emergency room with symptoms of coughing and weakness. After a decrease in blood platelet (PLT) and leukocyte (WBC) values in blood tests that were made in the emergency room, she was referred to the psychiatry outpatient clinic because of the recent use of antidepressants. Other examinations (chest X-ray and blood biochemistry test) made in the emergency room were normal. It was learned that the patient did not use alcohol or cigarettes, and had no medication except paroxetine in her medical history. The patient's complete blood count (CBC) values in the first examination in the emergency room were: white blood cells (WBC): $3.8 \times 10^{3} / \mu \mathrm{L}$, red blood cells $(\mathrm{RBC})$ : $3.99 \times 10^{6} / \mu \mathrm{L}$, hemoglobin (HGB): $12.3 \mathrm{~g} / \mathrm{dL}$, hematocrit (HCT): $36.6 \%$, and platelets (PLT): $123 \times 10^{3} / \mu \mathrm{L}$. The $\mathrm{CBC}$ test was repeated in our psychiatric outpatient clinic one day after the results of first tests. In that test, the following results were found: WBC: $2.8 \times 10^{3} / \mu \mathrm{L}$, RBC: $4.10 \times 10^{6} / \mu \mathrm{L}, \mathrm{HGB}: 12.7 \mathrm{~g} / \mathrm{dL}, \mathrm{HCT}: 38.1 \%$, PLT: $125 \times 10^{3} / \mu \mathrm{L}$. When the hospital records were examined, WBC: $7.9 \times 10^{3} / \mu \mathrm{L}$ and PLT: $193 \times 10^{3} / \mu \mathrm{L}$ were determined 3 weeks before the emergency room tests.

The patient, who had no symptoms such as bleeding or bruising, and whose WBC and PLT values were decreased, stopped paroxetine treatment and was referred 
to the hematology department. No additional hematologic disease was detected and the patient was followed up by the hematology outpatient clinic. On the $15^{\text {th }}$ day after stopping the paroxetine, the patient had normal platelet and leukocyte numbers. To treat the patient's depression, duloxetine $60 \mathrm{mg} /$ day was started because its hematologic adverse effects are rare (Gupta et al. 2007), and she was followed up by the psychiatry outpatient clinic. The patient's symptoms reduced one month later, her Beck Depression Score decreased to 16 and the hematologic parameters were normal. The patient continues to be followed up with the current treatment.

\section{DISCUSSION}

In this case report, a case of bicytopenia was reported after paroxetine treatment started and leukocyte and platelet levels reached normal limits after paroxetine was stopped.

Hematologic adverse effects due to psychotropic drugs are rare but important because they are life-threatening. The incidence is $1-2$ people per 100,000 each year. Middle age and being female are high risk factors. The mortality rate of hematologic adverse effects due to psychotropic drugs is 8-17\% (Oyesanmı et al. 1999). Almost all classes of psychotropic agents have been reported to cause blood dyscrasias. Mechanisms include direct toxic effects upon the bone marrow, the formation of antibodies against hematopoietic precursors or involve peripheral destruction of cells. Agranulocytosis is probably the most important drug-related blood dyscrasia (Flanagan \& Dunk 2008). In the paroxetine product monograph, thrombocytopenia is specified as a rare adverse effect, and leucopenia and anemia as infrequent adverse effects. (Available from: https://ca.gsk.com/ media/530543/paxil_pm-2014-11-13.pdf)

Only a limited number of cases were shared in a few journals about thrombocytopenia or leukopenia caused by paroxetine (Koçer et al. 2012, Sözeri-Varma et al. 2012, Moselhy \& Conlon 1999, Trewet et al. 2007, Ono et al. 2013). However, there are no cases of bicytopenia caused by paroxetine. In a study with 40 patients with depression, leukopenia was detected in 2 patients using a combination of lamotrigine and paroxetine, but no leukopenia was detected in the group that used paroxetine only (Normann et al. 2002).

Owing to the fact that symptoms that would be lifethreatening were detected incidentally with no clinically symptoms and there are no previous cases reported of bicytopenia caused by paroxetine (PubMed, Google Scholar), we would like to publish the findings to add to the literature.

Clozapine is associated with various haematological adverse effects (Herceg et al. 2010). Although clozapine is the first to come to mind regarding leukopenia and agranulocytosis it should not be forgotten that hematologic adverse effects may be seen rarely with other drugs in psychiatric practice. Non-symptomatic detection of bicytopenia during blood tests can be considered great fortune for this patient. If this condition had not been detected in the patient, and leukocyte and thrombocyte counts continued to decrease, it would have led to serious adverse effects such as life-threatening infection and bleeding. Anticoagulant drug use and hemorrhagic disorder should be questioned in patients using SSRIs as antidepressants, and it may be possible to protect against adverse effects that may be lethal. In addition, caution should be exercised in patients who undergo surgical interventions while using SSRIs.

\section{Acknowledgements: None.}

\section{Conflict of interest: None to declare.}

\section{Contribution of individual authors:}

Erkan Kuru: research idea, study design, manuscript writing, literature search;

Illker Özdemir: manuscript writing, literature search, study design;

Mehmet Hakan Türkçapar. research idea, study design, manuscript writing.

\section{References}

1. Flanagan RJ, Dunk L: Haematological toxicity of drugs used in psychiatry. Human Psychopharmacology: Clinical and Experimental 2008; 23:27-41

2. Gupta S, Nihalani N, Masand P: Duloxetine: review of its pharmacology, and therapeutic use in depression and other psychiatric disorders. Annals of Clinical Psychiatry 2007; 19:125-132

3. Halperin D, Reber G: Influence of antidepressants on hemostasis. Dialogues Clin Neurosci 2007; 9:47-59

4. Herceg M, Mužinić L, Jukić, V: Can we prevent blood dyscrasia (leucopenia, thrombocytopenia) and epileptic seizures induced by clozapine. Psychiatria Danubina 2010; 22:85-89

5. Koçbıyık S, Batmaz S, Turhan L, Yüncü ÖA, Çayköylü A: Fluoksetin ve Essitalopram Tedavisi Sonrası Gelişen Ekimotik Lezyonların Reboksetin Tedavisi ile Düzelmesi. Çukurova Üniversitesi Tip Fakültesi Dergisi 2015; 40:90-93

6. Koçer M, Zincir S, Yükselir C, Ak M: Paroxetine Induced Thrombocytopenia: A Case Report. Bulletin of Clinical Psychopharmacology 2012; 22:S123

7. Matsuura H, Kimoto S, Harada I, Naemura S, Yamamuro $K$, Kishimoto T: Lithium carbonate as a treatment for paliperidone extended-release-induced leukopenia and neutropenia in a patient with schizoaffective disorder; a case report. BMC psychiatry 2016; 16:161

8. Moselhy HF, Conlon W: Neutropenia associated with paroxetine. Irish Journal of Psychological Medicine 1999; 16:75-75

9. Nevel RM, Gontkovsky ST, Bryman E. Williams BE: Paroxetine-The Antidepressant from Hell? Probably Not, But Caution Required. Psychopharmacol Bull 2016; 46:77-104 
10. Normann C, Hummel B, Scharer L, Hörn M, Grunze H, Walden J: Lamotrigine as adjunct to paroxetine in acute depression: a placebo-controlled doubleblind study. J Clin Psychiatry 2002; 63:337-44

11. Ono S, Suzuki Y, Someya T: Prolongation of idiopathic thrombocytopenic purpura associated with paroxetine administration. General hospital psychiatry 2013; 35:213e13

12. Oyesanmi O, Kunkel EJS, Monti DA, Field HL: Hematologic side effects of psychotropics. Psychosomatics 1999; 40:414-421
13. Sadock BJ, Sadock VA: Kaplan and Sadock's synopsis of psychiatry: behavioral sciences/clinical psychiatry. Lippincott Williams \& Wilkins, Philadelphia, 2011

14. Sözeri-Varma G, Çulha-Ateşci F, Keskin A, Şimşe D: Paroksetin'e Bağll Trombosit İşlev Bozukluğu: Vak'a Sunumu. Yeni Symposium 2012; 50:112-115

15. Taylor D, Paton C, Kapur S: The Maudsley prescribing guidelines in psychiatry. John Wiley \& Sons, Inc, New York, 2015

16. Trewet CB, Galioto NJ, Payne TJ: Leukopenia associated with paroxetine use. Journal of Pharmacy Technology 2007; 23:166-168

\section{Correspondence:}

Erkan Kuru, MD

Boylam Psikiyatri Hastanesi

Ankara-İstanbul TEM Otoyolu, Kahramankazan Kavsağı, Lojistiküstü yanı, Kahramankazan, Ankara 06890, Turkey E-mail: erkankuru83@gmail.com 